\title{
Autonomy or integration: Historical analysis of the debate on the purpose of Icelandic local self-government
}

\author{
Eva Marín Hlynsdóttir, Assistant Professor, Faculty of Political Science, \\ University of Iceland
}

\begin{abstract}
An ongoing debate on the purpose of local self-government in Iceland has been simmering mainly between those who believe that local authorities should amalgamate in order to assume more responsibilities and those who believe that local autonomy, understood as the right of citizens to govern their own jurisdictions, should not be weakened. The purpose of this study is to discuss the role of local self-government in Iceland from these two very different perspectives by situating it within the context of the Nordic model of local self-government. This study's findings reveal that the Icelandic central government has successfully introduced functional reforms at the local level over the past 25 years, but it has not been as successful in initiating territorial reforms. The findings also show that conflict between the ideologies of the traditional autonomous model and the more modern model of integration is growing.
\end{abstract}

Keywords: Amalgamation; integration; autonomy; path dependency; local self-government.

\section{Introduction}

The existing literature on local government typically places all Nordic countries under the Nordic model. ${ }^{1}$ Traditionally, the Nordic model is epitomised by relatively small local

Icelandic Review of Politics and Administration. Vol. 14, Issue 1. Special issue on power and democracy in Iceland (83-100)

C 2018 Contact: Eva Marín Hlynsdóttir, evamarin@hi.is

Article first published online May $31^{\text {st }} 2018$ on http://www.irpa.is

Publisher: Institute of Public Administration and Politics, Gimli, Sæmundargötu 1, 101 Reykjavík, Iceland

Stjórnmál \& stjórnsýsla. 1. tbl. 14. árg. 2018. Sérhefti um vald og lýđræđi á Íslandi (81-100) Fræđigreinar

(C) 2018 Tengiliđur: Eva Marín Hlynsdóttir, evamarin@hi.is

Vefbirting 31. maí 2018 - Birtist á vefnum http://www.irpa.is

Útgefandi: Stofnun stjórnsýslufræđa og stjórnmála, Gimli, Sæmundargötu 1, 101 Reykjavík

DOI: https://doi.org/10.13177/irpa.a.2018.14.1.4

This work is licensed under a Creative Commons Attribution 3.0 License. 
governments and a high concentration of local government control over service delivery, which, in some cases, predates World War II. There are fundamental differences between the Nordic model and models based on the Napoleonic system that rely heavily on administrative centralisation with strong central oversight over local elites who reside in small municipalities with limited responsibilities. However, local politicians are often not only influential on the local level but also on the national level (Goldsmith 2010; Sellers \& Lidström 2007). Furthermore, a heavy emphasis on welfare service delivery has led to high levels of professional local bureaucracy (Goldsmith \& Larsen 2004). Correspondingly, issues such as economic competitiveness or regional development attract less attention at the local level. Politics at the local level is based on consensus, which Goldsmith and Larsen (2004) assert is associated with a 'strong corporatist tradition in decision-making at both national and local levels' (p. 123). They argue that this tradition is manifested in a lack of strong political leadership. Thus, local leadership entails collective, not individual, actions. Consequently, local leaders in the Nordic model are less likely to have a strong territorial role than French local leaders, for example. This situation is summed up nicely by Kuhlmann and Wollmann $(2014,18)$ : '[Nordic] countries possess a highly decentralised administrative structure, with, by tradition, politically and functionally strong local governments'. This high level of autonomy is further confirmed in the Local Autonomy Index (LAI) in which (unlike the above research findings) Iceland is also included (Ladner, Keuffer \& Baldersheim 2015).

The Nordic local government model is basically an ideal type, which means that within the model there is room for considerable country-specific differences. Nevertheless, a functionally strong local government is seen as a prerequisite to belonging to the Nordic model (Rose \& Ståhlberg 2005). As Iceland shares both historical and cultural roots with the other Nordic countries, Icelandic local government should be an integral part of the Nordic model. However, there are reasons to believe that the traditions of Icelandic local government do not fit the ideal of the Nordic model. First, Icelandic local government is not as functionally robust as the local governments of its Nordic counterparts (Kristinsson 2001), and second, in Iceland, local leadership has more unique features that often play a strong territorial and representative role in government (Hlynsdóttir 2016b). These differences are especially apparent in the Icelandic debate on local self-government, which is embedded in the rhetoric of large and functionally strong local governments versus small and democratically autonomous local authorities (Eythórsson 2014).

This paper explores the development of the debate over the purpose of Icelandic local self-government by using historical institutionalism as the analytical framework. The aim is twofold: first, to describe the historical development and traditions of Icelandic local self-government, and second, to identify possible explanations for the Icelandic local system's deviation from the Nordic model.

\section{Exploring local self-government and reform}

Reforms of local government have been on the agenda across Europe continuously since the early 1990s. The intensity and importance of the debate have risen and fallen 
during this time but have never quite vanished (Vetter \& Kersting 2003). Various types of reforms may be identified, although they all draw upon at least one of the three core values of local self-government: autonomy, democracy and efficiency (Sharpe 1970). Vetter and Kersting (2003) suggest that reforms may be organised into four types: territorial and/or functional reforms, management reforms, participatory reforms and reforms to representative democracy (p. 15). The main focus of this paper is on issues in relation to the first type of reform: territorial and/or functional reforms. Kuhlmann and Wollmann (2014) further subdivide this category to distinguish between functional and territorial profiles. However, they recognise that there is a close relationship between the two. Often, these two reform types are considered as almost interchangeable, although territorial reform is usually seen as a prerequisite to functional reform. This view emphasises the notion that to be able to decentralise or assign tasks on the local government level, local government needs a certain level of capacity that is usually achieved through extensive amalgamation. The emphasis on the relationship between size and local democracy may partly be traced back to Dahl and Tufte's (1973) seminal work, Size and Democracy, as well as to the work of Sharpe (1970) and Newton (1982) on the relationship between size, effectiveness and democracy.

The approach emphasising efficiency is often referred to as the consolidation perspective, an adversary of the public choice perspective (Baldersheim \& Rose 2010, 8). The former emphasises creating larger governing units that can supposedly take advantage of scale in providing services, thereby offering greater governance capacity and being altogether more capable of responding to citizens' needs. Conversely, the public choice approach stresses small local authorities and the democratic accessibility that smallness ensures for citizens (Keating 1995). Baldersheim and Rose (2010) also assert that the former highlights production efficiency, while the latter stresses allocation efficiency.

Kjellberg $(1985,1995)$ states that whichever approach gets the upper hand must observe certain ideological traditions. He identified two different models: the autonomous model and the integrational model. Under the autonomous model, central and local government belong to different domains of government. Although the role of local government is to preserve core values of liberty, democratic participation and efficiency, it functions more or less independently from the central government. The integrational model, however, regards the core task of local government to be the implementation of national policies, thereby advocating for a centralised government. Kjellberg also suggests that the integrational model is more in line with modern organisation of welfare services at the local level.

Identifying patterns of conflict is another method of evaluating reforms in which centre-periphery cleavage is a major source of political conflict over territorial reforms (Baldersheim \& Rose 2010, 15; Valen, Narud \& Harðarson 2000, 109-110) as local elites battle national elites. Another source of possible conflict is the urban-rural divide (Baldersheim \& Rose 2010a; Sandberg 2010). Its importance varies considerably according to country; thus, it is highly context sensitive. In the Icelandic context, both cleav- 
ages have proven to be highly relevant in explaining the presence of political conflict (Hlynsdóttir \& Önnudóttir forthcoming).

When it comes to explaining the development of local government reforms, this study relies on historical institutionalism, which draws on the idea that policy choices initially made when an institution or a policy programme is created will have a lasting influence on the institution or policy in the future. This introduces the concept of 'path dependency', i.e. once a government programme gets on track, there is a strong tendency for the initial policy choices to persist long after the programme's commencement (Peters 2012, 70). Approaches to path dependency vary, but Thelen (1999) argues that path dependency includes elements that concern not only continuity, but also organised change. Therefore, 'institutional arrangements cannot be understood in isolation from the political and social setting in which they are embedded' (Thelen 1999, 384).

Although widely applied in political science (e.g. Kuhlmann \& Wollmann 2014; Baldersheim \& Rose 2010), historical institutionalism is often suspected of struggling to explain institutional change. This has been addressed by various political scientists and sociologists. Consequently, there is considerable variance in how change is explained within the approach. On the one hand, some researchers perceive change as an evolution taking place incrementally, such as Hay's (2002) 'punctuated evolution' (p.163) or Pierson's (2003) 'slow-moving causal processes' (p.181). On the other hand, there are those who believe changes happen in a more radical and disruptive manner. These approaches include the 'formative moments' introduced by Rothstein (1998), the concept of 'critical junctures' from Collier and Collier (1991), Krasner's (1984) 'punctuated equilibriums' and the idea of 'policy windows' promoted by Kingdon (2003). ${ }^{2}$ Following the example of other studies that use historical institutionalism to explain territorial and administrative reforms (Baldersheim \& Rose 2010a; Kuhlmann \& Wollmann 2014), this paper applies Kingdon's (2003) policy window approach to describe changes in path dependency. The policy window can be summed up in the three streams of governmental process-problems, policies and political streams-coming together at a critical time and resulting in a policy opportunity surfacing. Kingdon explains that the opening of a policy window affects the decision-making agenda, which may or may not result in a decision being made within the government process.

\section{Setting the scene: Local self-government in Iceland}

There are two levels of government in Iceland-national and local-spread over 74 municipalities. Additionally, there are eight regional associations (Landshlutasamtök) that seem to function more as an inter-municipal cooperation scheme (IMC) than as a third level of government. Local self-government is protected under the 78th Article of the Icelandic Constitution but without independent power to levy taxes. The foundation of the Local Government Act no. 138/2011 centres around the idea that all local governments are assigned the same tasks. Based on the rule of negative delimitation of power (Baldersheim, Rose \& Sandberg 2017), the general precept is that local government is permitted to take on any task that is not forbidden by law or assigned to other bod- 
ies by law (Valsson 2014). This gives local authorities significant room to manoeuvre. Furthermore, task allocation between Icelandic central and local governments has long been known as notoriously complicated (Kristinsson 2001). Tasks that have been assigned to the local level include aspects of social services, such as financial assistance, housing and disability services, and education, including preschools, childcare and primary schools. They bear sole responsibility in the areas of planning, land use, building permits, sewerage and disaster management, among others. They are also responsible for public transportation through regional associations. This incomplete list provides an overview of the multitude of tasks that local authorities must manage on a daily basis. Of these tasks, education has proven to be the costliest, swallowing up roughly 50 percent of the average municipality's revenue. Disability services have also proven to be very costly, although they are supposed to be covered by earmarked government grants. However, grants have been criticised for being underfunded (Freysteinsdóttir \& Jónsson 2016). The main funding for local government comes from its share of the income tax (60 percent), followed by property taxes (12 percent). The equalisation fund is also an important funding source ( 8 percent), and for very small municipalities it constitutes a major source of income. The final revenue stream is through income on various services (19 percent). These are average numbers and may vary among municipalities.

With a population of roughly 340,000, Iceland's population is only a fraction of that of other Nordic nations. As the island is vast, this also means that population density is extremely low, with an average of 3.3 citizens per square kilometre. This is further exacerbated by the fact that roughly 65 percent of the population lives in Reykjavík, the capital city, and its suburbs. If this is extended up to a $70 \mathrm{~km}$ radius, then 77 percent of the population lives within an hour's drive from Reykjavík city centre. Furthermore, beyond a $100 \mathrm{~km}$ radius of Reykjavík there is only one major town with more than 5,000 residents: Akureyri, in North Iceland, with its population of roughly 18,000. The rest of the country is divided unequally between rural farmland and tiny villages and towns. Although the capital region is relatively large when compared to both other parts of the country and other Nordic countries as well, the Icelandic scenario is an extreme version of this trend.

The unequal distribution of people affects local governments. The $74^{3}$ municipalities in Iceland average 4,533 residents each, but if Reykjavík is excluded, the average drops to 2,912 . The most comparable Nordic country in this regard is Norway, with an average of 11,000 residents per municipality. Iceland is more like Norway and Finland when it comes to its tradition of having very small municipalities. Nevertheless, the proportion of municipalities with fewer than 5,000 residents is much higher in Iceland than in Norway and Finland (each at roughly 50 percent), as only nine of Iceland's 74 municipalities are home to more than 5,000 residents. Overall, Icelandic councils are also smaller than their Nordic counterparts, ranging from 5-15 members each, with two-thirds of the nation's councils having from five to seven members. Political parties affiliated with national parties are present in most of the councils with more than seven members but are not usually present in five-member councils. 
Finally, Icelandic local governments' share of the total public expenditure is considerably lower than it is in other Nordic countries, at roughly 30 percent. In the other Nordic countries, it is considerably higher (Baldersheim et. al. 2017). Furthermore, roughly 12 percent of the workforce is employed by local governments, (K. Björnsson 2014) compared to 20 percent in Norway and 25 percent in Sweden (Blom-Hansen, Borge \& Dahlberg 2010).

Consequently, Iceland's welfare system has developed differently, as local authorities are less involved in providing services than they are in other Nordic nations both when it comes to the overall share of public expenditure and percentage of the countries workforce.

\section{History of local self-government in Iceland}

\section{Early years}

Icelandic municipalities can trace their origins to at least as far back as the 13th century. Although the current structure of the local government system was created in 1872, it did nothing to disrupt the old geographical boundaries. Based on the Danish Local Government Act, the changes initiated in 1872 were mainly aimed at the internal structure of local government. Like the Danish approach, it introduced a three-tier system of towns, municipalities and districts (sýslur) on one level; regions (amt) on the second level (Blom-Hansen 2012); and central government on the third. The second tier was abolished in 1904; since then, the system has had a municipal level (consisting of towns, municipalities and districts) and a central government level. The 1872 Local Government Act established the council-committee model with a monistic structure (Wollmann 2004) as the basis for the Icelandic local government system. As the Danish Local Government Act had been designed in such a way that there were separate acts for each town and one collective act for all the other municipalities, the Icelandic Act was drafted in the same manner. Therefore, different rules applied to towns (in this case only Reykjavík in the beginning) and rural areas or small villages. In each town, the office of executive mayor or council manager was developed, while in municipalities, the council leader (oddviti) was simultaneously the political leader and municipal manager. Furthermore, like in the Danish market town system (Blom-Hansen 2012), mayors in towns were originally appointed by the central government. This was practised well into the 20th century in Iceland, with the last town to have a centrally appointed mayor eliminating the system in 1938.

In rural areas, the 1872 system (Tilskipun um sveitarstjórn á Íslandi) introduced councils usually consisting of three to five members and the voting system was personal or direct. The individual with the highest number of votes in local elections usually became leader of the council. This individual then led council meetings and handled the day-to-day management of the municipality. These individuals often stayed in office for a long time, becoming something of a local king (breppakóngar). In the early 1990s, most local council elections used this system. During the 2010-2014 election terms, 18 municipali- 
ties were still using the personal voting election system (Statistics Iceland 2015), with 12 council leaders who were managing local governments having been elected based on this old tradition. A new law, 138/2011, changed this system slightly, with council leaders elected via personal voting no longer automatically becoming de facto managers of the local authority.

Article 78 in the Icelandic Constitution was already part of the first constitution introduced in 1874. The constitution was based on the Danish Constitution (da. grundloven) of 1849, which was based on the Belgian Constitution of 1830 (Sigurðsson 2000). Originally, the ideological foundation of these laws was to provide local elites with mechanisms to protect them from interference from the king's officials. Valsson (2014) asserts that based on the origins of the Icelandic constitution, article 78 provides democratically elected councils with the right to a certain level of independence. Furthermore, it also leads to the conclusion that democratically elected councils have the right to govern without interference from the central government.

Two important conclusions can be drawn from this discussion. The first is that the local government system retained strong traits from the Napoleonic system well into the 20th century. The second is that the origins and heritage of local autonomy place the central-local relationship structure clearly within the autonomous model (Kjellberg 1985, 1995). As will be discussed later, this has had a lasting impact on the development of local government in Iceland.

\section{Urban-rural divide and centre-periphery cleavage}

It is possible to argue that there are two clear cleavages in Iceland: the centre-periphery cleavage and the urban-rural divide. Although closely linked, they are not fully aligned. Compared with other Nordic countries, urbanisation was slow to develop in Iceland. At the beginning of the 20th century, the vast majority of the population lived on rural farmland. Towns that did exist consisted of only a few hundred or a few thousand individuals. Reykjavík had a population of only 6,000 residents in the early 20th century. The conservative farming population was sceptical of urbanisation, viewing their rural traditions as incompatible with it. It may be argued that certain aspects of the Local Government Act of 1872 helped further differentiate between rural and town communities. The Danish tradition of distinguishing market towns from more rural areas had a long-lasting effect on the development of local Icelandic governments. Although towns and municipalities were viewed as autonomous entities, unlike the towns, the municipalities were not entirely independent. A group of municipalities that was usually based on districts was assigned to an inter-municipal district committee (sýslunefnd). The district committee was a semi-regional entity responsible for various shared services, e.g. rural road infrastructure or organised sheep herding. Furthermore, the district committee was also responsible for municipal finances, which meant that the municipalities were interdependent.

In his seminal work on local government, L. Björnsson (1972) identified the interdependence of municipalities as one of the major reasons why many booming towns 
and villages fought hard to win town rights during the early and middle 20 th century. As the fishing villages began to expand, they wanted money to invest in their infrastructure, but to obtain bank loans, their neighbouring municipalities within the district committee needed to approve their financial schemes. Many of the more rural and conservative areas found it difficult to accept such risky financial plans. This led to the tradition of a clear demarcation between urban and rural settlements. In Denmark, the distinction between town and rural municipalities was completely removed in 1970 (Blom-Hansen 2012). In the Icelandic context, the distinction was partly removed in the $1960 \mathrm{~s}$, but it did not completely vanish until the Local Government Act of 1986 (no. 8/1986) as the last traces of district committees were abolished.

In the early 1950s, there were 229 municipalities and towns in Iceland. In addition to the establishment of numerous urban settlements, mainly by the seaside, the landscape at the local level changed dramatically as people flocked from the rural countryside to the capital region. At the same time, the election system was skewed in favour of the periphery, as a disproportionate number of voters led to peripheral constituencies having more parliamentarians than constituencies around Reykjavik. This gave political parties with strongholds in the periphery, such as the Progressive Party (farmers' party), a disproportionately large role in government. Although the last reforms of the electoral voting system made some substantial changes, the periphery constituencies continue to have disproportionally large representation in parliament. Furthermore, the system was steeped in favouritism, and parliamentarians from the periphery in particular were accused of being exceptionally capable of bringing favours and goods to their own constituencies (Kristinsson 2015). In some ways, this established a system of distrust in which the periphery accused the centre of bullying and arrogance, and in return, the centre accused the periphery of being backward and pig-headed. Recently, such rhetoric has been apparent in public debates (see, for example, newspaper articles from Atlason 2008 \& Birkisson 2018).

Similar differences between more rural areas and main hubs of politics and business are visible in the other Nordic countries, especially Norway and Finland. However, whereas the periphery in Finland seems to be losing power (Sandberg 2010), the Norwegian periphery remains steadfast (Baldersheim \& Rose 2010b). The Norwegian electoral system is similar to Iceland's, as the rural north has a proportionally larger presence in parliament than the Oslo area (Baldersheim \& Rose 2011; Guðmundsson \& Eythórsson 2013).

\section{Stagnation at the local level}

In 1943, a journal article was published on the issue of local government. In it, concerns were raised on the number and size of municipalities in relation to their tasks (Guðmundsson 1943). Similar concerns were voiced in other articles over the following years. The main arguments in these articles were based on the idea of efficiency, i.e. that there were too many small municipalities that were unable to take on more responsibility in the development of the welfare state (Eythórsson 2014). These ideas were influenced by the similar concerns that were being voiced in other Nordic countries around the middle 
the century. However, unlike in other Nordic countries, where this momentum was used to substantially reduce the number of municipalities (Baldersheim \& Rose 2010b; Lidström 2010; Mouritzen 2010; Sandberg 2010), not much happened at the local level in Iceland. In the decades to come, the issue of local government reform surfaced from time to time without much changing. For example, in the 40 years between 1950 and 1990, the number of municipalities dropped by only 25, from 229 to 204, of which 13 were amalgamated in 1990.

Mouritzen (2010) describes how, during this same period, Danish local administration was professionalised by more university graduates entering the upper ranks of local bureaucracy. The trend helped create a break between politics and administration. Furthermore, Mouritzen points out that during this period the Danish system continued on its path to decentralisation and increased the role of local government in the provision of social services. The situation in Iceland during that time was radically different-it witnessed a period of stagnation that had an interesting side effect on the development of Icelandic local administration and governance. As towns were responsible for the streets, sewerage and waste management within their jurisdictions, most of them had developed a certain level of administrative capacity by the early 1990s. Their governments were capable of taking on more responsibility and expanding their capacity more efficiently than rural municipalities. This resulted in a double system. By the early 1990s, most rural municipalities had no visible administration-instead, their main administrator was a part-time council leader and a part-time clerk. There were no preschools, no rubbish collection, very few social services and no infrastructure, etc. (Hlynsdóttir 2015). Furthermore, most tasks that local authorities took on were not legally assigned to them but were taken on voluntarily. Therefore, the role of local leaders was often entrepreneurial (Hlynsdóttir 2016b) rather than that of someone merely overseeing and evaluating services and service provisions. This is clearly demonstrated in the fact that local government share of the total public expenditures in Iceland in the early 1990s were roughly 20 percent, while they were closer to 60 percent in the other Nordic countries (Eythórsson 1999). Nevertheless, as the discussion above shows, other Nordic countries' local governments were much better equipped to take on new tasks when the welfare state began to emerge (Sellers \& Lidström 2007) than local governments in Iceland. However, the 1990s ushered in new ideas and new approaches at the Icelandic local government level.

\section{Modern Icelandic local government}

In neighbouring countries and throughout the Western world, there was a strong trend toward government reorganisation during the 1980s (Pollitt \& Bouckaert 2011). The period since 1991 in particular may be viewed as one of constant change at the Icelandic local government level. New ideas, which later became known collectively as the new public management, were also influencing how Icelandic central government viewed the role of government. In 1991, a coalition government of the Independence Party and the Social Democrats came into power. Minister of Municipal Affairs Jóhanna Sigurðardót- 
tir had a clear agenda to promote decentralisation at the local level (Eythórsson 1998). The initial idea was to follow the 1970 Danish example in which municipalities were amalgamated first and tasks were decentralised later (Mouritzen 2010). The plan was to initiate large-scale territorial reform in 1993. The aim was to reduce the number of municipalities to 43 (Eythórsson 2014). Although the initiative was based on the same premise as the Danish approach, in that citizens and local leaders were informed of the benefits of amalgamation (Mouritzen 2010), there was one major difference. Given the tradition of local autonomy in Iceland, the Local Government Act of 1986 ( $\mathrm{L} \ddot{\mathrm{g}} \mathrm{um}$ sveitarstjórnir 8/1986) stipulated that citizens must be allowed to vote on the amalgamation processes. Additionally, for the mergers to go forward in each existing municipality, voter majorities were required to approve them. In the end, the initiative failed. Only one new municipality emerged directly out of the initiative, although other amalgamations followed at later stages (Eythórsson 2014).

A second top-down initiative on behalf of the central government (Independence Party-Progressive Party coalition) was introduced by the Progressive Party's minister of local government in 2005 as amalgamation referendums were held in 66 municipalities. The plan was to cut the number of municipalities down to 56. Again, the initiative was only partly successful. Only one new municipality emerged directly from the initiative, but like before, several others followed in its aftermath (Eythórsson 2014). In hindsight, neither of these results is surprising as large-scale and top-down-driven amalgamations have usually failed when local referendums have been used to decide the fate of the amalgamation (Kuhlmann \& Wollmann 2014).

Askim, Klausen, Vabo and Bjurstrom $(2016,60)$ state that there are several driving factors behind amalgamation reforms, such as fiscal stress, urbanisation, decentralisation and recent amalgamation reforms. As for decentralisation, one of the main arguments for the 1993 amalgamation initiative was the idea that large-scale amalgamations were necessary before any meaningful functional reforms could take place (Eythórsson 2014). In the Nordic context, this approach was applied in all instances of successful reform. First, territorial reforms take place, then functional reforms follow in their wake (Baldersheim \& Rose 2010b; Lidström 2010; Mouritzen 2010; Sandberg 2010). In the case of Iceland, the reverse was true. Instead of cancelling proposed functional reforms, the government decided to embrace the opportunity they presented and push forward. New laws on social services had already been introduced in 1991 (no. 40/1991) which defined local government responsibilities in the area of social services in more detail. In 1996, the government began to delegate education through primary schools (no. 66/1995) and expanded local-level responsibilities in the area of planning and land use in 1998 (no. 73/1997). Furthermore, fundamental changes were made during this period to the overall structure of public administration with the introduction of the Administrative Law in 1994 (no. 37/1993) and the Information Act in 1996 (no. 50/1996). These acts had a significant effect on local administration as they required a level of administrative professionalism that went beyond what most local authorities were able to provide at the time. 
The most widely and rapidly felt change was the 1996 allocation of responsibilities for administering primary schools at the local level. This change is believed to have been the primary reason for the bottom-up territorial changes that took place (Hlynsdóttir 2002). Before the start of the amalgamation initiative in 1993, there were 196 municipalities in Iceland - a number that shrank to 124 in 2000 and to 79 by 2006. It may be argued that the first waves of amalgamation in 1994 (following the 1993 initiative) and 1998 were an immediate response to the changes in the school system. The second waves in 2002 and 2006 had somewhat different features from the previous waves, as in several cases amalgamations were being made with municipalities that had already amalgamated during the first wave. This is in line with the argument that once the status quo of an organisation is disrupted, it takes time to stabilise again, which opens up the possibility for repeated amalgamations of the same municipality (Askim et al. 2016).

In the decade since 2006, very little has happened regarding territorial changes and local authorities have directed their energies towards stabilising already-merged municipalities. Problems that have come up in relation to service provisions have been resolved through inter-municipal cooperation. This has led to an increase in various types of participatory schemes, and a recent survey estimates that local authorities participate in at least 300 inter-municipal cooperation schemes of various types and levels (Jóhannesson, Jóhannesson \& Eythórsson 2016). In the area of functional reforms, one major change occurred when the task of disability service was delegated to the local level in January 2012. As the provision of this service is both costly and complicated, it was stipulated in the law that municipalities must represent a service area of at least 8,000 residents. Furthermore, the local authorities took on the task of public transportation during this period, which is organised through regional associations.

The final issue that could be expected to influence territorial and functional reforms is the fiscal stress (Askim et al. 2016) following the financial crisis in 2008 that struck a heavy blow on many municipalities, although it seems that small rural municipalities escaped the crisis relatively unscathed. However, many of the larger and (before 2008) more booming towns absorbed significant financial losses (Kristinsson 2014). Nevertheless, only one amalgamation was a direct consequence of the crisis with the municipality of Álftanes merging with the town of Garðabær in 2012. Traditionally, Icelandic local authorities have enjoyed a significant degree of fiscal autonomy, especially in their spending and borrowing activities. One of the responses to the financial problems that many municipalities found themselves in after the crisis was to impose stricter fiscal regulations under the new Local Government Act of 2011.

Thus, it is possible to argue that since the early 1990s, Icelandic local authorities have been on the fast track to becoming more like those in other Nordic countries in terms of their functional responsibilities. Although top-down amalgamation initiatives have not been successful, functional reforms have been a success, bringing with them territorial reforms that have been initiated from the bottom up. However, functional reforms have shed light on structural weaknesses at the local level. Administrative capacity is still underdeveloped, and this has become particularly obvious in technically challenging areas, 
such as planning and land use, and many local leaders find these tasks difficult to tackle (Hlynsdóttir 2016a). Many local authorities also rely on a small number of core staff with a low degree of specialisation. In such cases, the council manager is often expected to compensate for the lack of administrative capacity (Hlynsdóttir 2016b). Furthermore, many local authorities are financially strapped because of high salary costs in the areas of education and disability services, as both functions require a large amount of staff. This, along with complications in relation to the number of IMCs and increased numbers of local government tasks, seems to be leading to a renewed interest in amalgamation among local governments. As a result, the overall number of Icelandic municipalities will be dropping down to 72 following the local elections in May 2018.

\section{The path dependency of Icelandic local government}

The major overhaul of the local government system after the Local Government Act of 1872 helped establish a new trend in the Icelandic local government system, and the changes were clearly ideologically influenced by the autonomous model (Kjellberg 1985, 1995). Consequently, in the 1950s an arrangement of highly autonomous local authorities was established in a system through which political conflict was based on centre-periphery cleavages on the one hand and urban-rural divides on the other.

Figure 1 shows the intersection of the two main sources of political conflict as well as the number of municipalities found within each quarter today. In the centre, which covers the immediate area of Reykjavík and its neighbouring cities, there are six cities and one small rural municipality on the outskirts of the area. Despite only accounting for a fraction of the country's municipalities, roughly 64 percent of Iceland's population lives in this area. The remainder of the country, or what here is referred to as the periphery, ${ }^{4}$ lies below the horizontal axis, accounting for 67 of the 74 municipalities (present in Iceland as of January 2018) but representing only 36 percent of the population. The minimum threshold to be identified as urban in this study is to be a town with at least 500 residents, ${ }^{5}$ which means there are several fairly large municipalities that fall into this rural-periphery group, as their population density is too low to be urban. Furthermore, the group of urban-periphery municipalities covers 32 percent of the population and 43 percent of the overall number of municipalities. By comparison, the group of rural-periphery municipalities accounts for only 4 percent of the population, but 47 percent of municipalities.

Generally, it is possible to view the initiation of change from two viewpoints: first, as a result of the motives and actions of rational actors, and second, as a result of changes within the external environment (Lowndes \& Roberts 2013). The emphasis on territorial change during the 1950s and 60s, as well as in the early 1990s, may be traced back to such external influences. In the former era, Denmark, along with the other Nordic countries, was actively incorporating the local level into the welfare service system. The influence of this is clearly visible in the discourse and arguments put forth in favour of territorial reforms (Eythórsson 2014). In the 1990s, the Icelandic government initiative was strongly influenced by the new public management wave, which was, at the time, 


\section{STJÓRNSÝSLA}

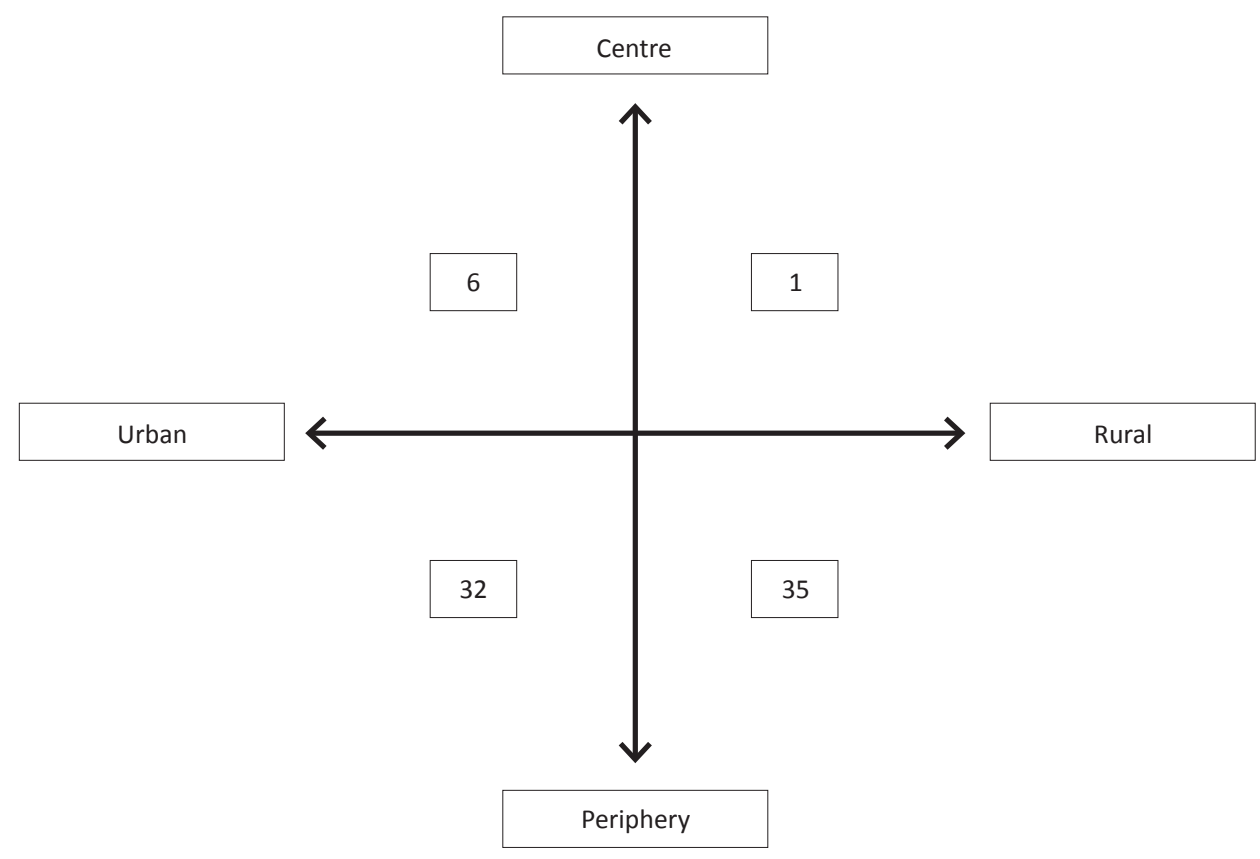

Figure 1. The two main sources of political conflict in relation to territorial reforms at the local level and the number of municipalities within each quarter

reaching its peak (Kristmundsson 2003). However, unlike the other Nordic countries, the window of opportunity (Kingdon 2003) opened and closed again in Iceland without any major top-down territorial reforms being initiated. The same occurred during the government-initiated amalgamation election in 2005, although in this case the initiative was purely actor-driven, as it was not possible to identify any external influences at the time.

Kingdon (2003) asserts that to open a policy window successfully, the three process streams - problems, policies and politics - must intersect. Applying this rule to the Icelandic situation reveals a unique trend. First, the problem stream is present, and it emerges through the fact that during this time, there is always a group of actors who view the situation as a problem and who actively seek a solution to the problem, usually by suggesting large-scale territorial reform. As the numerous reports and policy proposals on the issue of territorial reforms in the past 40 years show, the second stream of policy proposals is present as well. Therefore, the main obstacle to territorial reforms lies within the political stream.

The political stream includes the national mood, campaigns by pressure groups, political ideology and election results, as well as changes within the administration (Kingdon 2003, 145). In the Icelandic context, it seems that pressure groups have not yet played a large part, leaving the main arena to political parties and local elites. Although 
it is difficult to pinpoint any particular political ideology that is explicitly against territorial reform, political parties have hesitated to openly suggest compulsory territorial reforms. The only party that has actively and openly argued for such a move is the Social Democratic Alliance (Samfylking), which is ideologically related to the Social Democrats who led the Ministry of Local Government during the widespread attempt at amalgamation in 1993. The Social Democratic Alliance entered the ministry again in 2007 and the minister openly suggested setting one-thousand-resident limits on municipalities. However, these ideas were overshadowed by the financial crisis in 2008 and have not resurfaced since. The electoral base of the parties that have been in power for the bulk of this time-the Independence Party (Sjalfstcodisflokkur) and the Progressive Party (Framsóknarflokekur) - is drawn from the periphery. Members of parliament (MPs) representing these parties have usually been particularly careful not to mention compulsory amalgamation, although a notable exception is the Progressive Party minister of local government in 2005. Furthermore, research has shown that MPs from the periphery, regardless of their party origins, enjoy a much closer relationship with local elites than MPs from the capital area (Hlynsdóttir \& Önnudóttir forthcoming). Therefore, changes within the parliamentary composition have not resulted in any major changes to territorial structure.

The final and probably most important issue is national mood (Kingdon 2003). The analysis reveals that the national mood traditionally leans strongly in favour of local government autonomy. Consequently, political forces have not received the necessary public support to implement compulsory territorial reforms. Furthermore, in the cases of top-down territorial initiatives, opponents have been quick to seek support in the rhetoric of the centre-periphery cleavage, as well as the urban-rural divide.

However, it is wrong to claim that there have been no changes at the local level, even though these changes have taken place much more slowly and incrementally than many would have preferred. The implementation of functional reforms during this era has initiated territorial reforms driven from the bottom up. Furthermore, local authorities have not been as successful in blocking functional reforms as they have been in thwarting territorial changes. Thus, it may be argued that the central government, at least to some extent, has reformed government on the local level over the past 25 years.

\section{Discussion}

The findings of this study show that Icelandic government structure at the local level has persisted on a path of maintaining high autonomy and a large number of small and densely populated municipalities since the establishment of the current system in the late 19th century. All major attempts on behalf of the central government to initiate territorial reforms have been thwarted mainly by using the ideology of the autonomous model (Kjellberg 1985, 1995) in relation to a mixture of rhetoric based on the centreperiphery cleavage on the one hand and the urban-rural divide on the other. Hence, the sources of political conflict already established in the early 20th century are as alive and 
well today as they were then. Consequently, the government has not been able to use openings in policy windows successfully due to a negative national mood, thereby resulting in a lack of political resilience when it comes to territorial reforms.

However, at the same time, and reminiscent of the Nordic model, the government has successfully delegated important tasks to local governments, such as the provision of primary education, planning and disability services and welfare services (Baldersheim et al. 2017). Unlike territorial reforms, it is difficult to apply the rhetoric of political conflict that is embedded in the centre-periphery cleavage or the urban-rural divide to the ideology of functional reforms. As a result, sceptical local authorities have not been able to stave off the trend of functional reform. This has led to a situation in which several municipalities, although only representing a small segment of the overall population, have had serious difficulties fulfilling their obligation to provide welfare services. The use of IMCs to solve this problem has shed light on efficiency problems and potential democratic deficiencies.

It can be argued that in the past 25 years, the interpretation of the role of local authorities has gone from accepting them as relatively inert (insofar as providing welfare services) to viewing them as active 'participants in large spheres of public activity' (Kjellberg 1995, 49). At the same time, the traditional perception of municipalities as ultra-autonomous becomes increasingly troublesome as it stands in direct conflict with the role of local governments as service providers. As a result, it is likely that as the weaknesses of the current system become more apparent to the public, the national mood surrounding compulsory amalgamation will shift. However, given the persistence of the dependency path in the existing institutional situation, it may be some time until we experience a major break from the current system of local government in Iceland.

\section{Notes}

1 Sometimes referred to as the Scandinavian model.

2 For an informative overview of different approaches, see Peters (2012) and Thelen (1999).

3 Although the number of municipalities will be reduced to as few as 72 in the spring of 2018, the current number of municipalities will be used for analytical purposes.

4 There is a heated debate in Iceland over what should be considered the periphery (landsbyggð). This analysis relies on the traditional view of interpreting the Reykjavík capital area and its immediate suburbs as unique when compared to other parts of the country. A more nuanced approach to distinguishing between different levels of settlements outside the capital area is for example found in Vifill Karlssons PhD Thesis; Transportation improvement and interregional migration from 2012. The application of the centre-periphery cleavage in this paper however, follows closely the example laid out by Baldersheim and Rose in their 2010 book on territorial reform in Europe, Territorial Choice.

5 'Urban' as a concept lacks a precise definition within the literature on Icelandic local government. A recent definition put forth by the European Union sets the threshold for urbanisation at 5,000 residents (Dijkstra \& Poelman, 2014). However, in the Icelandic context, the level is set at 500 residents because villages of this size are more likely to offer a certain level of services, e.g. shops, small businesses and centres of public services, whereas villages with fewer residents are often more similar to hamlets than villages. 


\section{References}

Administrative Act 37/1993 [Stjórnsýslulög] (1997). Alpingistíðindi vefútgáfa. Retrieved from https:// www.althingi.is/lagas/nuna/1993037.html

Askim, J., Klausen, J.E., Vabo, S.I., and Bjurstrom, K. (2016). "What Causes Municipal Amalgamation Reform? Rational Explanations Meet Western European Experiences, 2004-2013”, in S. Kuhlmann and G. Bouckaert (eds.), Local Public Sector Reforms in Times of Crisis: National Trajectories and International Comparisons (pp. 59-80). London: Palgrave Macmillan.

Atlason, G. (2008). "Byggðastefna við Austurvöll og í dreifbýli”, Mbl.is. Retrieved from https://www. mbl.is/greinasafn/grein/1191955/

Baldersheim, H., and Rose, L.E. (2010a). "Territorial Choice: Rescaling Governance in European States", in H. Baldersheim and L.E. Rose (eds.), Territorial Choice: The Politics of Boundaries and Borders (pp. 1-20). Basingstoke: Palgrave Macmillan.

Baldersheim, H., and Rose, L.E. (2010b). "The Staying Power of the Norwegian Periphery", in H. Baldersheim and L. E. Rose (eds.), Territorial Choice: The Politics of Boundaries and Borders (pp. 80-100). Basingstoke: Palgrave Macmillan.

Baldersheim, H., and Rose, L.E. (2011). "Norway: The Decline of Subnational Democracy?” in J. Loughlin, F. Hendriks, and A. Lidström (eds.), The Oxford Handbook of Local and Regional Democracy in Europe (pp. 282-306). Oxford: Oxford University Press.

Baldersheim, H., Rose, L.E., and Sandberg, S. (2017). "Local and Regional Government in the Nordic Countries: Co-Operative Decentralization", in O. Knutsen (ed.), The Nordic Models in Political Science: Challenged but Still Viable? (pp. 193-218). Oslo: Fagbokforlaget.

Birkisson, D.F. (2018). "Segir rökprota Ásmund ala á tortryggni”, Fréttablaðið. Retrieved from https:// www.frettabladid.is/frettir/segir-roekrota-asmund-ala-a-tortryggni

Björnsson, K. (2014). "Hlutur sveitarfélaga í umfangi hins opinbera", Samband islenskera sveitarfélaga. Retrieved from http://www.samband.is/um-okkur/sjonarmid/nr/1977

Björnsson, L. (1972). Saga sveitarstjórnar á Íslandi siddara bindi. Reykjavík: Samband íslenskra sveitarfélaga.

Blom-Hansen, J. (2012). "Local Government in Denmark and the 2007 Municipal Reform", in A. Moisio (ed.), Rethinking Local Government: Essays on Municipal Reform (pp. 43-82). Helsinki: Government Institute for Economic Research. Vatt Publications, 61. Retrieved from https://www.yumpu.com/ en/document/view/51163338/61-rethinking-local-government-essays-on-municipal-reform-vatt

Blom-Hansen, J., Borge, L.E. and Dahlberg, M. (2010). "Local Government in Denmark, Norway and Sweden", in A. Moisio (ed.), Local public sector in transition: A Nordic perspective (pp.63-154). Helsinki Government institute for Economic Research. Vatt Publications, 56. Retrieved from www.doria.fi/ bitstream/handle/10024/148891/j56.pdf?sequence=1

Collier, R.B., and Collier, D. (1991). Shaping the Political Arena. Princeton: Princeton University Press.

Dahl, R.A., and Tufte, E.R. (1973). Size and Democracy. Stanford: Stanford University Press.

Dijkstra, L., and Poelman, H. (2014). A Harmonised Definition of Cities and Rural Areas: The New Degree of Urbanisation (Regional Working Papers No. WP 01/2014). Retrieved from http://ec.europa.eu/ regional_policy/sources/docgener/work/2014_01_new_urban.pdf

Eythórsson, G.T. (1998). Kommunindelningspolitik i Island: Staten, kommunerna och folket om kommunsammanslagningar. Göteborg: Göteborg Universitet.

Eythórsson, G.T. (1999). "Iceland", in B. Jacob, W. Linder, R. Nabholz, and C. Hierli (eds.), Democracy and Local Governance: Nine Empirical Studies (pp. 62-88). Bern: Institute of Political Science, University of Bern.

Eythórsson, G.T. (2014). "Sameining sveitarfélaga á Íslandi i 70 ár. Röksemdir sameiningarsinna og andstæðinga", Icelandic Review of Politics \& Administration 10(1), 143-168. DOI: https://doi. org/10.13177/irpa.a.2014.10.1.8

Freysteinsdóttir, F.J., and Jónsson, G. (2016). "Yfirfærsla á málaflokki fatlaðs fólks frá ríki til sveitarfélaga: Með sérstakri áherslu á stærsta sveitarfélagið, Reykjavík”, Icelandic Review of Politics \& Administration 12(2), 443-466. DOI: http://doi.org/10.13177/irpa.a.2016.12.2.12 


\section{STJÓRNSÝSLA}

Goldsmith, M. (2010). "Central Control over Local Government - A Western European Comparison", Local Government Studies 28(3), 37-41.

Goldsmith, M., and Larsen, H.O. (2004). "Local Political Leadership: Nordic Style", International Journal of Urban and Regional Research 28(1), 121-133.

Guðmundsson, B., and Eythórsson, G.T. (2013). "Vægi atkvæða og pólitískt jafnrétti”, Íslenska Djóðfélagið 4, 39-63.

Guðmundsson, J. (1943). "Var rétt að afnema ömtin”, Sveitarstjórnarmál 3(1), 4-15.

Hay, C. (2002). Political Analysis: A Critical Introduction. Basingstoke: Palgrave Macmillan.

Hlynsdóttir, E.M. (2002). “Áhrif lýðræðispátta á sameiningarferli í Skagafirði”, Sveitarstjórnarmál 3(62), $32-34$.

Hlynsdóttir, E.M. (2015). “Ordførermakt eller rådmannsmakt: Lokalpolitisk lederskap på Island”, in N. Aarsæther and K.H. Mikalsen (eds.), Lokalpolitisk. lederskap i Norden (pp. 69-87). Oslo: Gyldendal Akademisk.

Hlynsdóttir, E.M. (2016a). "Administrative Capacity and Long-Term Policy Making at the Icelandic Local Level”, Icelandic Review of Politics \& Administration 12(2), 237-258. DOI: http://doi.org/10.13177/ irpa.a.2016.12.2.3

Hlynsdóttir, E.M. (2016b). "Leading the Locality: Icelandic Local Government Leadership Dilemma", Lex Localis 14(4), 807-826. DOI: http://doi.org/10.4335/14.4.807-826(2016)

Hlynsdóttir, E.M. (2016c). "Professionalism among Icelandic Mayors: Job Postings, Experience and Education as Determinants of Professionalism at the Icelandic Local Level", Icelandic Review of Politics \& Administration 12(1), 5-26. DOI: http://doi.org/10.13177/irpa.a.2016.12.1.1

Hlynsdóttir, E.M., and Önnudóttir, E.H. (forthcoming). "Constituency Service in Iceland and the Importance of the Centre-Periphery Divide", Representation.

Information Act 50/1996 [Upplýsingalög] (1996). Alpingistíðindi vefútgáfa. Retrieved from https:// www.althingi.is/lagas/124/1995066.html

Jóhannesson, A.P., Jóhannesson, H., and Eythórsson, G.T. (2016). Samstarfsverkefni sveitarfélaga. Retrieved from https://www.rha.is/static/files/Rannsoknir/2016/samstarf_sveitarfelaga_lokaskyrsla.pdf

Keating, M. (1995). "Size, Efficiency and Democracy: Consolidation, Fragmentation and Public Choice", in D. Judge, G. Stoker, and H. Wolman (eds.), Theories of Urban Politics (pp. 117-134). London: Sage Publications.

Kingdon, J.W. (2003). Agendas, Alternatives, and Public Policies (2nd ed.). New York: Longman.

Kjellberg, F. (1985). "Local Government Reorganization and the Development of the Welfare State", Journal of Public Policy 5(2), 215-239. DOI: http://doi.org/10.1017/S0143814X00003032

Kjellberg, F. (1995). "The Changing Values of Local Government", The Annals of American Academy of Political and Social Science 540(1), 40-50.

Krasner, S. (1984). "Approaches to the State: Alternative Conceptions and Historical Dynamics", Comparative Politics 16(2), 223-46.

Kristinsson, G.H. (2001). Staðbundin stjórnmál: Markmið og árangur sveitarfélaga. Reykjavík: Háskólaútgáfan.

Kristinsson, G.H. (2015). "Political Control and Perceptions of Corruption in Icelandic Local Government", Icelandic Review of Politics \& Administration 11(1), 1-18. DOI: http://doi.org/10.13177/ irpa.a.2015.11.1.1

Kristmundsson, Ó.H. (2003). Reinventing Government in Iceland: A Case Study of Public Management Reform. Reykjavík: Háskólaútgáfan.

Kuhlmann, S., and Wollmann, H. (2014). Introduction to Comparative Public Administration: Administrative Systems and Reforms in Europe. Cheltenham: Edward Elgar.

Ladner, A., Keuffer, N., and Baldersheim, H. (2015). Local Autonomy Index for European Countries (1990 2014). Release 1.0. Brussels: European Commission.

Lidström, A. (2010). "The Swedish Model Under Stress: The Waning of the Egalitarian, Unitary State?” in H. Baldersheim and L.E. Rose (eds.), Territorial Choice: The Politics of Boundaries and Borders (pp. 61-79). Basingstoke: Palgrave Macmillan. 
Local Government Act [Tilskipun um sveitarstjórn á Íslandi] (1872). Iceland: Tíðindi frá Alpingi Íslendinga. Fjórtánda ping. 1873 síðari partur.

Local Government Act 8/1986 [Lög um sveitarstjórnir] (1986). Alpingistíðindi vefútgáfa. Retrieved from http://www.althingi.is/lagas/139b/1998045.html

Local Government Act 138/2011 [Lög um sveitarstjórnir] (2011). Alpingistíðindi vefútgáfa. Retrieved from http://www.althingi.is/lagas/nuna/2011138.html

Lowndes, V., and Roberts, M. (2013). Why Institutions Matter: The New Institutionalism in Political Science. Basingstoke: Palgrave Macmillan.

Mouritzen, P.E. (2010). "The Danish Revolution in Local Government", in H. Baldersheim and L.E. Rose (eds.), Territorial Choice: The Politics of Boundaries and Borders (pp. 21-41). Basingstoke: Palgrave Macmillan.

Newton, K. (1982). "Is Small Really So Beautiful? Is Big Really So Ugly? Size, Effectiveness, and Democracy in Local Government", Political Studies 30(2), 190-206.

Peters, B.G. (2012). Institutional Theory in Political Science: The New Institutionalism (3rd ed.). New York: Continuum.

Pierson, P. (2003). "Big, Slow-moving and Invisible: Macrosocial Process in the Study of Comparative Politics", in J. Mahoney and D. Rueschemeyer (eds.), Comparative Historical Analysis in the Social Sciences (pp. 177-207). Cambridge: Cambridge University Press.

Planning and Land Use Act 73/1997 [Skipulags- og byggingarlög] (1997). Alpingistíðindi vefútgáfa. Retrieved from https://www.althingi.is/lagas/138b/1997073.html

Pollitt, C., and Bouckaert, G. (2011). Public Management Reforms (3rd ed.). Oxford: Oxford University Press.

Primary School Act 66/1995 [Lög um grunnskóla] (1995). Alpingistíðindi vefútgáfa. Retrieved from https://www.althingi.is/lagas/124/1995066.html

Rose, L.E., and Ståhlberg, K. (2005). "The Nordic Countries: "Still the Promised Land?” in B. Denters and L.E. Rose (eds.), Comparing Local Governance. Trends and Developments (pp. 83-99). Basingstoke: Palgrave Macmillan.

Rothstein, B. (1998). "Political Institutions - An Overview", in R.E. Goodin and H.-D. Klingemann (eds.), A New Handbook for Political Science (pp. 133-166). Oxford: Oxford University Press.

Sandberg, S. (2010). "Finnish Power-Shift: The Defeat of the Periphery?", in H. Baldersheim and L.E. Rose (eds.), Territorial Choice: The Politics of Boundaries and Borders (pp. 42-60). Basingstoke: Palgrave Macmillan.

Sellers, J.M., and Lidström, A. (2007). "Decentralization, Local Government, and the Welfare State", Governance 20(4), 609-632. DOI: http://doi.org/10.1111/j.1468-0491.2007.00374.x

Sharpe, L.J. (1970). "Theories and Values of Local Government”, Political Studies 18(2), 153-174.

Sigurðsson, J.T. (2000). "Sjálfstjórn sveitarfélaga”, Úlfjótur 53(2), 143-189.

Statistics Iceland. (2015). "Local Government Elections 31 May 2014”, Hagtidindi, (November), 1-48.

Thelen, K. (1999). "Historical Institutionalism in Comparative Politics", Annual Review of Political Science (1), 369-404. DOI: http://doi.org/10.1146/annurev.polisci.2.1.369

Tilskipun um sveitarstjórn á Íslandi. (1872). Tỉ̇indi frá Alpingi Íslendinga. Fjórtánda ping. Síðari partur.

Valen, H., Narud, H.M., and Harðarson, Ó.T. (2000). "Geography and Political Representation", in P. Esaiasson and K. Heidar (eds.), Westminster and Congress: The Nordic Experience (pp. 107-131). Columbus: Ohio State University Press.

Valsson, T.F. (2014). Sveitarstjórnarréttur. Reykjavík: Codex.

Vetter, A., and Kersting, N. (2003). "Democracy versus Efficiency? Comparing Local Government Reforms Across Europe", in N. Kersting and A. Vetter (eds.), Reforming Local Government in Europe: Closing the Gap between Democracy and Efficiency (pp. 11-28). Opladen: Leske+Budrich.

Wollmann, H. (2004). "Urban Leadership in German Local Politics: The Rise, Role and Performance of the Directly Elected (Chief Executive) Mayor", International Journal of Urban and Regional Research 28(March), 150-165. 